\title{
Photosynthesis and carbon gain under contrasting light levels in seedlings of a pioneer and a climax tree from a Brazilian Semideciduous Tropical Forest
}

\author{
MILENE SILVESTRINI ${ }^{1}$, IVANY FERRAZ MARQUES VÁLIO ${ }^{1}$ and \\ EDUARDO ARCOVERDE DE MATTOS 2,3
}

(received: January 19, 2006; accepted: August 23, 2007)

\begin{abstract}
Photosynthesis and carbon gain under contrasting light levels in seedlings of a pioneer and a climax tree from a Brazilian Semideciduous Tropical Forest). In this study we evaluated photosynthetic characteristics and patterns of biomass accumulation in seedlings of two tree species from a Semideciduous Tropical Forest of Brazil. Seedlings of Trema micrantha (L.) Blum. (pioneer) and Hymenaea courbaril (L.) var. stilbocarpa (Hayne) Lee \& Langenh. (climax) were grown for 4 months under low light (LL) (5\%-8\% of sunlight) and high light (HL) (100\% of sunlight). Under HL, T. micrantha showed higher $\mathrm{CO}_{2}$ assimilation rates $\left(\mathrm{A}_{\mathrm{CO}_{2}}\right)$ and light saturation than $\mathrm{H}$. courbaril. Under LL, $\mathrm{A}_{\mathrm{CO}_{2}}$ were higher in H. courbaril. Under LL, total chlorophyll and carotenoid contents per unit leaf area were higher in $H$. courbaril. Chlorophyll $a / b$ ratio was higher in $T$. micrantha under both light regimes. $\mathrm{A}_{\mathrm{CO}_{2}}$ and $\mathrm{F}_{\mathrm{v}} / \mathrm{F}_{\mathrm{m}}$ ratio at both pre-dawn and midday in $\mathrm{H}$. coubaril were lower in $\mathrm{HL}$ indicating chronic photoinhibition. Thus, the climax species was more susceptible to photoinhibition than the pioneer. However, H. courbaril produced higher total biomass under both treatments showing high efficiency in the maintenance of a positive carbon balance. Thus, both species expressed characteristics that favor growth under conditions that resemble their natural microenvironments, but $H$. courbaril also grew under HL. The ecophysiological range of responses to contrasting light levels of this climax plant seems to be broader than generally observed for other rainforest climax species. We propose that this could be related to the particular spatio-temporal light regime of the semideciduous forests.
\end{abstract}

Key words - $\mathrm{CO}_{2}$ assimilation, growth response to light, Hymenaea courbaril, photoinhibition, Trema micrantha

RESUMO - (Fotossíntese e acúmulo de biomassa sob condições contrastantes de intensidade luminosa em plântulas de uma espécie pioneira e outra climácica de uma floresta estacional semidecidual do Brasil). Neste trabalho foram avaliadas características fotossintéticas e padrões de acúmulo de biomassa de duas espécies arbóreas de uma floresta estacional semidecidual. Plântulas de Trema micrantha (L.) Blum. (pioneira) e Hymenaea courbaril (L.) var. stilbocarpa (Hayne) Lee \& Langenh. (climácica) foram cultivadas por quatro meses sob baixa radiação (BR) (5\%-8\% da radiação solar incidente) e alta radiação (AR) (100\% da radiação solar incidente). Sob $\mathrm{AR}, T$. micrantha apresentou maiores taxas de assimilação de $\mathrm{CO}_{2}\left(\mathrm{~A}_{\mathrm{CO}_{2}}\right)$ e ponto de saturação luminosa. Sob BR, $\mathrm{A}_{\mathrm{CO}_{2}}$ foram maiores em H. courbaril. Sob BR, o conteúdo de clorofilas e carotenóides totais por unidade de área foliar foi maior em $H$. courbaril. A razão clorofila $a / b$ foi maior em $T$. micrantha sob os dois tratamentos. $\mathrm{A}_{\mathrm{CO}_{2}}$ e razão $\mathrm{F}_{\mathrm{v}} / \mathrm{F}_{\mathrm{m}}$ antes do amanhecer e no horário de máxima intensidade luminosa em $H$. courbaril foram menores sob AR, indicando a ocorrência de fotoinibição crônica. Apesar da suscetibilidade à fotoinibição, $H$. courbaril teve maior produção de biomassa. Desta forma, ambas as espécies apresentaram características que favorecem o crescimento sob as condições de seu ambiente natural, no entanto $H$. coubaril também cresceu em AR. A amplitude de respostas ecofisiológicas desta espécie sob condições contrastantes de intensidade luminosa parece ser mais ampla que o comumente observado em espécies climácicas de florestas tropicais úmidas. Nós propomos que isso pode estar relacionado ao regime de luz peculiar das florestas semidecíduas.

Palavras-chave - assimilação de $\mathrm{CO}_{2}$, fotoinibição, Hymenaea courbaril, resposta do crescimento à luz, Trema micrantha

\section{Introduction}

The environmental heterogeneity created by gap dynamics in the tropical forests, especially light quality and intensity, is probably related to different selective

\footnotetext{
1. Universidade Estadual de Campinas, Instituto de Biologia, Departamento de Fisiologia Vegetal, Caixa Postal 6109, 13083-970 Campinas, SP, Brazil.

2. Universidade Federal do Rio de Janeiro, Instituto de Biologia, Departamento de Ecologia, Caixa Postal 68020, 21941-970 Rio de Janeiro, RJ, Brazil.

3. Corresponding author: eamattos@biologia.ufrj.br
}

pressures that affected the characteristics of life cycles of tropical tree species during their evolution (Pickett 1983, Martínez-Ramos 1985). Thus, many species show different adaptive strategies according to microhabitat distribution in the forest. In general, seedlings of pioneer species (sensu Swaine \& Whitmore 1988) have higher photosynthetic rates than climax species as well as higher biomass accumulation, lower values of photosynthetic efficiency and less pigment contents (Strauss-Debenedetti \& Bazzaz 1991, Zipperlen \& Press 1996, Huante \& Rincón 1998). These responses seem to be related to mutually exclusive strategies presented by pioneer and 
climax species (Pickett 1983). Pioneer species grow and occupy rapidly the gaps with ample availability of resources, such as light and nutrients. However, they tend to be less competitive than climax species under the low radiation prevailing in the understory (Bazzaz 1979). The climax species can maintain a positive carbon balance under low radiation (shade tolerants) due mainly to morphological and physiological characteristics that confer higher light use efficiency, and an increase in biochemical defense against herbivores and pathogens (Pickett 1983, Bazzaz 1984, Kitajima 1994, Henry \& Aarssen 1997). However, this higher photosynthetic efficiency of climax species is only expected under low radiation. Under high radiation these species supposedly do not cope efficiently with more radiation than the capacity of photosynthetic utilisation. Thus, these species would be more sensitive to photoinhibition than pioneer species (Lovelock et al. 1994).

Nevertheless, these patterns were studied mainly in tropical rainforests. There is a lack of information on the species of Tropical Semideciduous Forests. Whilst in rainforests rainfall ranges from 2000 to $4000 \mathrm{~mm}$ per year (Chazdon 1986, Phillips et al. 1994) or even more (Holdridge 1967), in the semideciduous forests the values are between 1000 to $2000 \mathrm{~mm}$ (Holdridge 1967, Hogan et al. 1995, Morellato \& Leitão-Filho 1995, Oliveira-Filho $\&$ Fontes 2000). Moreover, the climate of semideciduous forests is characterized by two distinct seasons, a wet and hot and a dry and cold one. In the latter, many species lose their leaves (IBGE 1992, Hogan et al. 1995). Furthermore, the light regime is also different from other forests due to a more illuminated understory (Chazdon \& Fetcher 1984, Chazdon 1986, Gandolfi 2000). A large spatial variability in light intensity should also be expected in semideciduous forests mainly during the dry season. Gandolfi (2000) observed integrated values of light from 2.8 to $10.9 \mathrm{~mol} \mathrm{~m}^{-2}$ day $^{-1}$ in areas with predominance of deciduous species in the understory of a semideciduous forest in southeasthern Brazil. In contrast, in rainforests Chazdon \& Fetcher (1984) did not report seasonal differences in understory light levels with values around 0.21-0.32 $\mathrm{mol} \mathrm{m}^{-2}$ day $^{-1}$.

Although Kitajima (1994) and Hogan et al. (1995) studied photosynthetic and growth characteristics of semideciduous tree species from Panama, they did not emphasize the possible differences of responses to light of species among forested systems. In the case of semideciduous forests, changes in light intensity for the understory plants will not depend exclusively on chance disturbance due to tree fall. Shifting in light regime, which occurs rather accidentally in rainforests, will occur seasonally in semideciduous forests due to phenology of component species. Moreover, the increase in radiation load during the dry season for understory plants is accompanied by a decrease in water availability, which may decrease the capacity of the photosynthetic apparatus for light utilization. This raises an interesting question on how the regeneration of climax species of the semideciduous forests is. We might expect that in the semideciduous forest photosynthetic and growth responses to light of seedlings of pioneer and climax species will be more similar to each other than generally found for rainforest species. In order to evaluate this, we compared under two contrasting light levels the photosynthetic responses, accumulation, and allocation of biomass in seedlings of Trema micrantha (L.) Blum. and Hymenaea courbaril (L.) var. stilbocarpa (Hayne) Lee \& Langenh., which were selected because they represent the extremes of pioneer and climax species categories in a Semideciduous Tropical Forest. (Ferreti et al. 1995, Rodrigues 1995, Souza 1996).

\section{Material and methods}

Species - We studied Trema micrantha (Ulmaceae) and Hymenaea courbaril var. stilbocarpa (Leguminosae, subfamily Caesalpinioideae), species frequently found in Brazilian Semideciduous Tropical Forests, which show life cycles typical of pioneer and climax species, respectively (Lorenzi 1992, Martínez-Ramos 1985, Ferreti et al. 1995, Gandolfi et al. 1995, Rodrigues 1995). Trema micrantha usually grows in gaps and at the edge of forests, whereas $H$. courbaril is a component of the canopy. Seeds of T. micrantha are positive photoblastic (Souza \& Válio 2001) or need temperature alternation for germination (Matthes 1992) and young plants show high growth rates (Rodrigues 1999). In contrast, $H$. courbaril has no light requirement for germination (Souza \& Válio 2001) and young plants show very low growth rates (Souza 1996, Rodrigues 1999). In addition, other climax species features, such as high quality wood (hard and heavy), long life span and formation of pools of understory seedlings, are also present (Ferreti et al. 1995, Rodrigues 1995).

Growth conditions - Fruits of T. micrantha and H. courbaril were collected from six and seven specimens, respectively, along four fragments of semideciduous forest of São Paulo, Brazil. Seeds of both species were germinated on vermiculite in trays in a glasshouse. After emergence, around 100 seedlings/ species were transplanted to $1.8-\mathrm{L}$ pots filled with a mixture of soil and sand (2:1). In order to maximise the exposition to solar radiation, pots were placed on benches in an open area in a north-south direction. Benches facing North were left without cover for the high light treatment (HL), whereas those facing South were covered with layers of black plastic woven screens fitted in a wooden frame to reduce radiation for the low light 
treatment (LL). The soil of the pots of both species was kept always moist and fertilized every 10 days with $100 \mathrm{ml}$ of Hoagland solution (Hoagland \& Arnon 1938). At the same interval, all the pots were randomly rearranged on the benches.

Integrated and maximal photon flux density (PFD) between $400-700 \mathrm{~nm}$ were recorded simultaneously in both treatments with LI-190SA quantum sensor and LI-191SA line quantum sensor attached to a LI-1000 datalogger (LI-COR, Inc. Lincoln, USA). Readings were recorded every $60 \mathrm{~s}$ for a period of $12 \mathrm{~h}$ from 6:30 AM to 6:30 PM. Data were recorded during the seedling growth period (end of summer) in three cloudless days. Integrated daily PFD was $4.0 \pm 0.2 \mathrm{~mol} \mathrm{~m}^{-2} \mathrm{~d}^{-1}$ and the maximum PFD was $260 \pm 26 \mu \mathrm{mol} \mathrm{m}^{-2} \mathrm{~s}^{-1}$ in the LL treatment. In contrast, integrated daily PFD was $50 \pm 4 \mathrm{~mol}$ $\mathrm{m}^{-2} \mathrm{~d}^{-1}$ and maximum $2347 \pm 117 \mu \mathrm{mol} \mathrm{m}^{-2} \mathrm{~s}^{-1}$ in the HL treatment ( $n=3$ days). At the end of the experiment, in the beginning of the winter, values fell to $1.4 \mathrm{~mol} \mathrm{~m}^{-2} \mathrm{~d}^{-1}$ of integrated PFD and $96 \mu \mathrm{mol} \mathrm{m}^{-2} \mathrm{~s}^{-1}$ of maximum PFD under LL and $28.5 \mathrm{~mol} \mathrm{~m}^{-2} \mathrm{~d}^{-1}$ of integrated PFD and $1581 \mu \mathrm{mol} \mathrm{m}^{-2} \mathrm{~s}^{-1}$ of maximum PFD under HL. LL treatment was around 5\%-8\% of daily PFD of HL.

Integrated PFD during the day in HL was approximately 2 -fold higher than the maximum value found in a large gap in a clear day of summer, whereas LL values were in the range of the ones registered in the understory of a tropical semideciduous forest in the dry season (Gandofi 2000). Mean daily temperatures during the experiment ranged from $18.2^{\circ} \mathrm{C}$ (minimum) to 28.3 ${ }^{\circ} \mathrm{C}$ (maximum). The variation of temperatures between the treatments was $5^{\circ} \mathrm{C}-10^{\circ} \mathrm{C}$, with higher values in $\mathrm{HL}$.

$\mathrm{CO}_{2}$ gas exchanges $-\mathrm{CO}_{2}$ gas exchange in both species was studied after a period of three months under experimental conditions. A portable open system (ADC, LCA-4, UK) was used. Measurements were recorded always during cloudless days in the $2^{\text {nd }}$ and $3^{\text {rd }}$ fully expanded leaves of T. micrantha and $H$. courbaril, respectively. Mean values of three to six measurements were considered as a measure of each leaf. Diurnal courses of $\mathrm{CO}_{2}$ exchange were carried out during three days on 5 plants per species per treatment (1 leaf/plant). However, due to similar results only one day was shown. Through these courses the time of maximum assimilation rate $\left(\mathrm{A}_{\max }\right)$ reached for each species under both treatments was determined. This time was used to obtain $\mathrm{A}_{\max }(n=10$ plants, 1 leaf/plant), transpiration rate (E) $(n=10)$, stomatal conductance $\left(g_{\mathrm{s}}\right)(n=10)$ and light response curves $(n=3$ plants, 1 leaf/plant). The three plants used for light response curves were selected from the ten plants used to obtain $\mathrm{A}_{\max }$. Other five plants were used for diurnal courses of $\mathrm{CO}_{2}$ exchange. These plants were used for the analysis of pigment content and biomass at the end of the experiment.

To reach enough light radiation to saturate photosynthesis for light response curves, plants of both species growing in LL were transferred to a glasshouse under a PFD of $\sim 1000 \mu \mathrm{mol} \mathrm{m}^{-2} \mathrm{~s}^{-1}$. Data were registered only after stabilisation at each light level and progressive reduction of light was obtained through shade screens over the leaf chamber. The measurements were carried out in ambient light and without any temperature control. In both species, leaf temperature during the measurements were around $24{ }^{\circ} \mathrm{C}$ $30{ }^{\circ} \mathrm{C}$. The adjustment of the curves was attained by nonrectangular hyperbola (Prioul \& Chartier 1977) using the program Photosyn Assistant (Dundee Scientific, UK), applying the following equation:

$$
A=\frac{\varnothing \cdot Q+A_{\text {sat }}-\sqrt{\left(\varnothing \cdot Q+A_{\text {sat }}\right)^{2}-4 \cdot \varnothing \cdot Q \cdot k \cdot A_{s a t}}}{2 k}-R_{\text {day }}
$$

where $A$ is the net $\mathrm{CO}_{2}$ assimilation rate; $A_{\text {sat }}$ is the net $\mathrm{CO}_{2}$ assimilation rate at light saturation; $\varnothing$ is the apparent quantum yield (AQY) (initial slope of the light response curve); $Q$ is the photon flux density (PFD); $k$ is the convexity of the light response curve and $R_{d a y}$ is the rate of diurnal dark respiration.

$\mathrm{A}_{\max }$ and $\mathrm{A}_{\text {sat }}$ data were expressed in both area and mass basis. $A_{\max }$ and $A_{\text {sat }}$ per unit mass were calculated dividing both measures in area basis by the mean of leaf mass per area $(\mathrm{LMA}=$ dry mass of leaves/total leaf area) obtained in biomass analysis.

Chlorophyll $a$ fluorescence - Emission of chlorophyll $a$ fluorescence was followed in 10 plants/treatment/species in the same leaves and in the same day of $\mathrm{A}_{\max }$ measurements. Data were registered before dawn and at midday (between 12:00AM and 2:00PM). Chlorophyll fluorescence was measured with a Plant Efficiency Analyser (HANSATECH, PEA 02.002, UK). The variable $F_{v} / F_{m}$ ratio was evaluated, where $F_{m}$ is the maximum fluorescence and $F_{v}$ is the variable fluorescence. $F_{v}$ is the difference between the maximum $\left(F_{m}\right)$ and minimum fluorescence $\left(\mathrm{F}_{0}\right)$. We allowed $20 \mathrm{~min}$ of leaf pre-darkening before applying a pulse of saturating light of $2700 \mu \mathrm{mol} \mathrm{m} \mathrm{m}^{-2} \mathrm{~s}^{-1}$ at the leaf surface.

Pigment content - Eight leaf discs of $0.3 \mathrm{~cm}^{2}$ per plant (5 plants/ species/treatment) were taken from plants growing for four months under experimental conditions. Discs were removed from the $2^{\text {nd }}$ and $3^{\text {rd }}$ fully expanded leaves of T. micrantha and $H$. courbaril, respectively. Each extract of eight discs was considered a replicate $(n=5)$. Pigments were extracted with pure acetone $(99.5 \%$ - 99.8\%) through maceration followed by filtration. Pigment concentration was determined in a spectrophotometer (Varian, 300, USA, $0.5 \mathrm{~nm}$ band resolution) according to Lichtenthaler (1987). We measured chlorophyll $a\left(\mathrm{C}_{\mathrm{a}}\right)$, chlorophyll $b\left(\mathrm{C}_{\mathrm{b}}\right)$, total chlorophylls $\left(\mathrm{C}_{\mathrm{a}}+\mathrm{C}_{\mathrm{b}}\right)$ and carotenoids $\left(C_{x+c}\right)$ in $\mathrm{mg} \mathrm{m}^{-2}$ of leaf area $\left(\mathrm{C}_{\mathrm{a}}=662 \mathrm{~nm}, \mathrm{C}_{\mathrm{b}}=645\right.$ $\mathrm{nm}$ and $\left.\mathrm{C}_{\mathrm{x}+\mathrm{c}}=470 \mathrm{~nm}\right)$. Chlorophyll $a / b$ ratio $\left(\mathrm{C}_{\mathrm{a}}: \mathrm{C}_{\mathrm{b}}\right)$ were also calculated.

Accumulation and allocation of biomass - At the end of the experiments, accumulation and allocation of biomass were assessed by recording height $(\mathrm{cm})$, leaf number from stem and lateral shoots (number of leaflets in $H$. courbaril) and dry mass of leaves, stems plus lateral shoots and roots of five plants/species/treatment. Total biomass, specific leaf area (SLA), leaf area (LA) and root:shoot ratio were also calculated. SLA was calculated based on leaf disc area and its dry mass obtained for pigment analysis (SLA $=$ disc area dry mass ${ }^{-1}$ ). LA was calculated by the following equation: $\mathrm{LA}\left(\mathrm{cm}^{2}\right)=$ dry 
mass of leaves x SLA x 1000. Dry mass was obtained after 48 h at $80^{\circ} \mathrm{C}$.

Statistical analysis - The variables were analyzed considering two factors: species and light intensity. Normality of distribution of data and variance homogeneity were tested through the tests of Kolmogorov-Smirnov and Bartlett, respectively (Zar 1996). For PFD at photosynthetic saturation $\left(\mathrm{PDF}_{\mathrm{sat}}\right), \mathrm{AQY}, \mathrm{E}$, $\mathrm{C}_{\mathrm{x}+\mathrm{c}}, \mathrm{C}_{\mathrm{a}}: \mathrm{C}_{\mathrm{b}}$, leaf number, height, leaf area, dry mass of leaves and roots and the following data transformed to logarithms in base 10: $\mathrm{A}_{\text {sat }}$ per unit area, LCP, $g_{s}, \mathrm{C}_{\mathrm{a}}, \mathrm{C}_{\mathrm{b}}, \mathrm{C}_{\mathrm{a}}+\mathrm{C}_{\mathrm{b}}$, stem plus lateral shoots dry mass and total dry mass, the analysis of variance followed by the Tukey test at $5 \%$ of probability of error was used to compare species and treatments. $\mathrm{A}_{\text {sat }}$ per unit mass was transformed into $\log (\mathrm{x}+1)$ and also analyzed by ANOVA. The Tukey test was applied according to Gomez \& Gomez (1984) when the interaction was significant. The Scheirer-Ray-Hare test, an extension of the Kruskal-Wallis test according to Sokal \& Rohlf (1995) and comparison of medians through the notched box plots (McGill et al. 1978; SYSTAT 1992) were applied for $R_{\text {day }}, A_{\max }$ in area and mass basis, $F_{v} / F_{m}$ ratio, SLA and root:shoot ratio. $A_{\max }$ in mass basis showed normal distribution and homogeneity of variances, however, to compare with $\mathrm{A}_{\max }$ in area basis we chose the notched box plots since results of ANOVA and non-parametric analysis were similar. Statistical analyses were performed in the software WinSTAT 3.1 Statistics for Windows 1991-1995 Kalmia Co. Inc., and notched box plots in Systat 5.0 1992.

\section{Results}

Light response curves - Trema micrantha under HL presented higher net assimilation rate at light saturation $\left(\mathrm{A}_{\mathrm{sat}}\right)$ than Hymenaea courbaril var. stilbocarpa, whereas H. courbaril showed higher $\mathrm{A}_{\text {sat }}$ values under LL (table 1). $\mathrm{A}_{\text {sat }}$ per unit mass was higher in T. micrantha than $H$. courbaril in both light treatments. For both species, $\mathrm{A}_{\text {sat }}$ per unit mass was higher in low light. Under HL $T$. micrantha presented higher light intensity at photosynthetic saturation than $H$. courbaril and plants under LL, whilst $H$. courbaril did not exhibit differences between light treatments (table 1). In both species, AQY was higher and LCP lower in plants grown under LL (table 1). Despite the highest diurnal dark respiration values of T. micratha under HL (median of $-0.53 \mu \mathrm{mol} \mathrm{m}{ }^{-2} \mathrm{~s}^{-1}$, mean of $-0.9 \pm$ $0.4 s_{\bar{x}}$-standard error), notched box plots did not show significant differences in medians among groups: median of -0.17 (mean of $-0.19 \pm 0.03 s_{\bar{x}}$ ) to T. micrantha under LL, median of -0.38 (mean of $-0.41 \pm 0.06 s_{\bar{x}}$ ) to $H$. courbaril under LL and median of -0.46 (mean of $-0.4 \pm$ $0.1 s_{\bar{x}}$ ) to $H$. courbaril under HL.

$\mathrm{CO}_{2}$ gas exchange and chlorophyll a fluorescence Diurnal courses of $\mathrm{CO}_{2}$ exchange are showed in figure 1. Under LL, $H$. courbaril showed higher values than $T$.

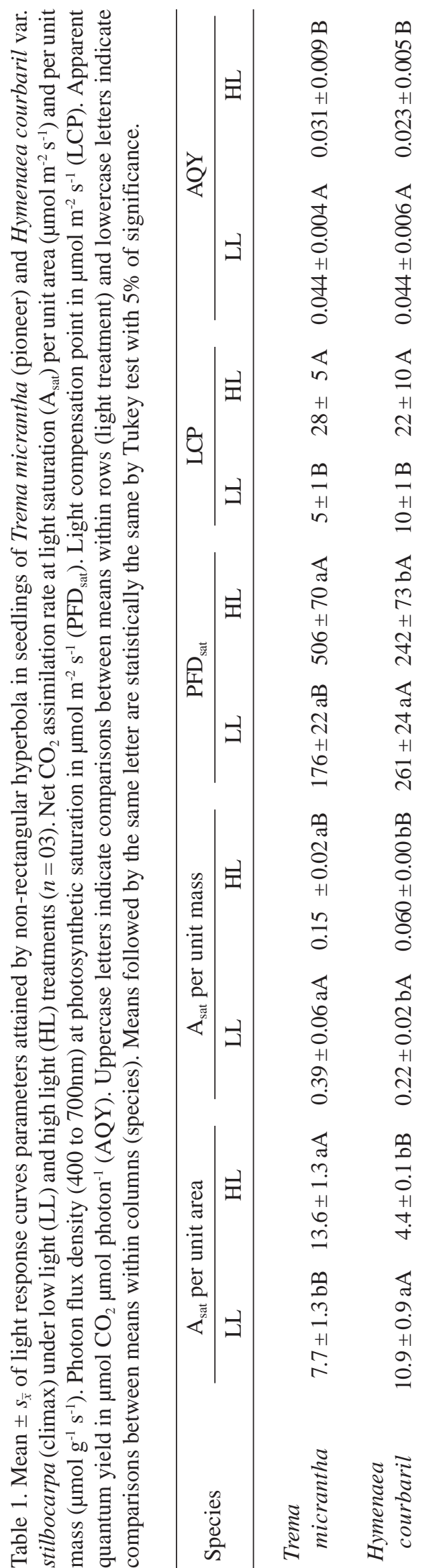


micrantha, whereas this was not the case under HL. The values observed for T. micrantha under HL were higher than in LL, whereas the values for $H$. courbaril were lower in HL than in LL. $\mathrm{CO}_{2}$ uptake was fairly constant during the middle of the day in both treatments and species.

$A_{\max }$ per unit area was statistically different between species and light regimes (figure 2A). The highest value was observed in T. micrantha under HL (median of $10.6 \mu \mathrm{mol} \mathrm{m} \mathrm{m}^{-2} \mathrm{~s}^{-1}$ ), and the lowest in $H$. coubaril in HL (median of $2.7 \mu \mathrm{mol} \mathrm{m} \mathrm{m}^{-2} \mathrm{~s}^{-1}$ ). Under LL, median values were 4.3 and $5.3 \mu \mathrm{mol} \mathrm{m} \mathrm{m}^{-2} \mathrm{~s}^{-1}$ for $T$. micrantha and $H$. courbaril. The highest value of $\mathrm{A}_{\max }$ on mass basis was shown by T. micrantha under LL (median value of $0.22 \mu \mathrm{mol} \mathrm{g} \mathrm{g}^{-1} \mathrm{~s}^{-1}$, figure $2 \mathrm{~B}$ ). $\mathrm{A}_{\max }$ of $T$. micrantha under HL and $H$. courbaril under LL were similar (median of 0.12 and $0.11 \mu \mathrm{mol} \mathrm{g}^{-1} \mathrm{~s}^{-1}$, respectively) and the lowest value was observed in $H$. courbaril under HL (median of $0.04 \mu \mathrm{mol} \mathrm{g} \mathrm{g}^{-1} \mathrm{~s}^{-1}$ ).

Stomatal conductance values were similar between LL and HL plants of T. micrantha as well LL plants of $H$. courbaril (table 2). However, H. courbaril under HL exhibited very low values of $g_{s}$. This retained its transpiration rate even under the higher radiation and temperature conditions of this treatment.

$\mathrm{F}_{\mathrm{v}} / \mathrm{F}_{\mathrm{m}}$ ratio followed the same trends at dawn and midday, although a higher decrease was observed for HL plants at midday (figure $2 \mathrm{C}$ and D). Under LL, $H$. courbaril and $T$. micrantha were very similar with medians around 0.8 , both at dawn and midday. Under
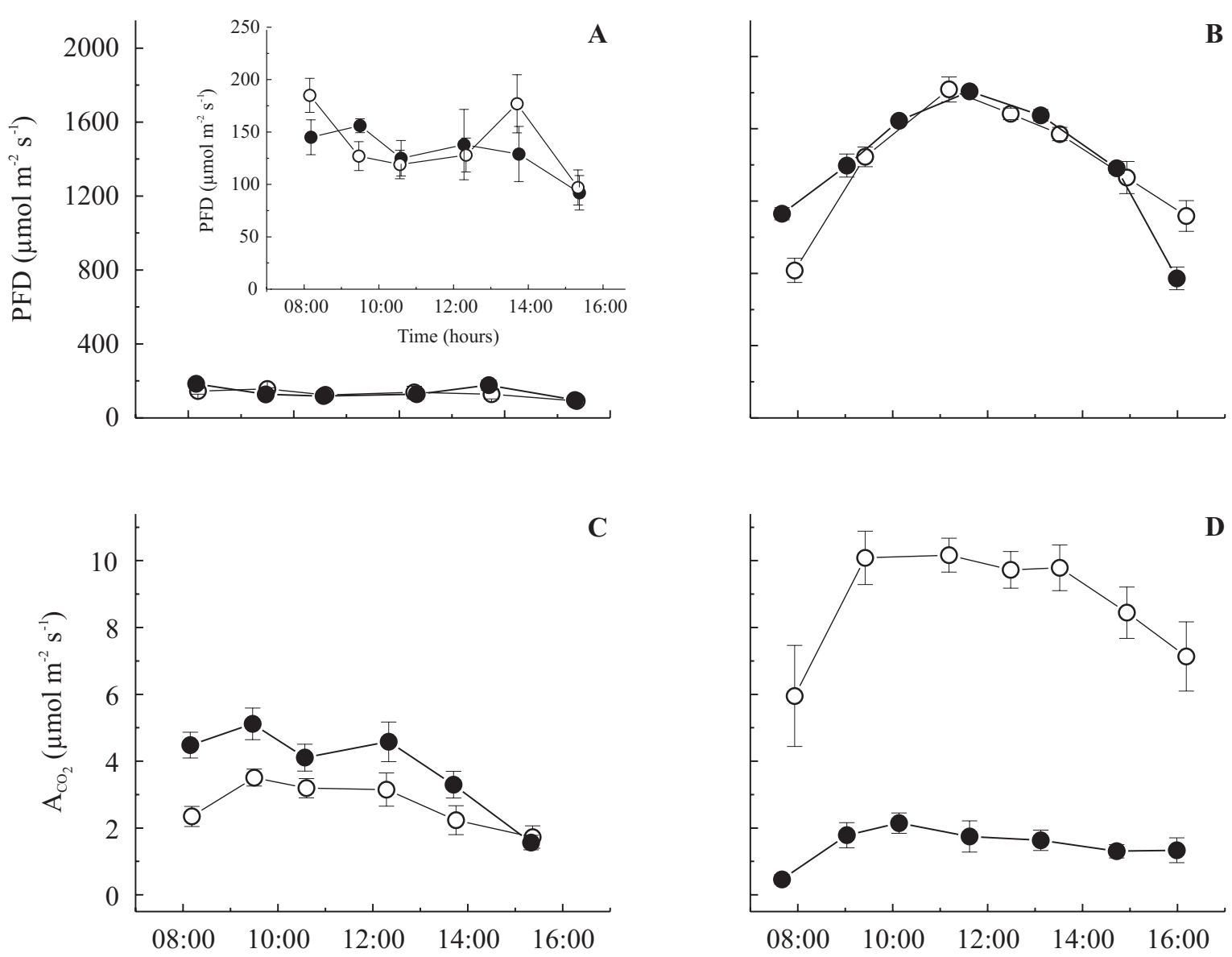

Time (hours)

Figure 1. Daily courses of photon flux density (PFD) and net $\mathrm{CO}_{2}$ exchange $\left(\mathrm{A}_{\mathrm{CO}_{2}}\right)$ for seedlings of Trema micrantha (pioneer) (०) and Hymenaea courbaril var. stilbocarpa. (climax) (•) under low light (A \& C) and high light (B \& D) treatments. The figure inside (A) is a minor scale representation of PFD under low light (daily integrated PPF were 3.41 and $3.57 \mathrm{mmol} \mathrm{m}^{-2}$ and for $\mathrm{A}_{\mathrm{CO}_{2}}$ 72 and $102 \mathrm{mmol} \mathrm{m}^{-2}$ for T. micrantha and H. courbaril, respectively). Under high light, integrated values of PFD were 43.6 and $44.6 \mathrm{mmol} \mathrm{m}^{-2}$ and for $\mathrm{A}_{\mathrm{CO}_{2}}$ were 252 and $47 \mathrm{mmol} \mathrm{m}^{-2}$ for T. micrantha and H. courbaril, respectively. Note: Error bars are lower than symbols in the largest scale of PFD, LL data. Mean $\pm s_{\bar{x}}$ for 5 plants. 
$\mathrm{HL}, \mathrm{F}_{\mathrm{v}} / \mathrm{F}_{\mathrm{m}}$ in $H$. courbaril was always significantly lower than in T. micrantha, with the lowest value observed at midday (median of 0.3).

Photosynthetic pigments, biomass accumulation and allocation - Chlorophyll $a$ and $b$ in leaves of $H$. courbaril grown under HL were lower than under LL (table 3). Chlorophyll $b$ in $H$. courbaril grown under HL was higher than in T. micrantha, whereas the opposite was found for chlorophyll $a$. Total chlorophyll content in H. courbaril was higher than in T. micrantha under LL, but under HL, no differences were observed. High values of total chlorophyll of $H$. courbaril under LL are due to high values of both chlorophyll $a$ and $b$ (table 3). T. micrantha presented higher values of chlorophyll $a: b$ ratio than $H$. courbaril, without any significant effect of light condition (table 3). Lower content of total carotenoids was found in leaves of T. micrantha grown under LL in relation to plants under HL as well as leaves of $H$. courbaril under LL (table 3). Under HL, no significant differences were found between species. $H$. courbaril showed higher levels of carotenoids under LL than HL.

$H$. courbaril had the tallest plants in both light treatments and plants in LL were the highest ones (table 4). Both species showed higher total leaf area under LL than HL. SLA of T. micrantha was higher than $H$. courbaril under LL and lower under HL (figure 3). $T$. micrantha and $H$. courbaril presented higher values of dry mass under HL than LL and $H$. courbaril presented higher values of all growth parameters than T. micrantha in both light conditions (table 5). Leaf dry mass of $H$. courbaril was the only parameter in which no significant difference was observed between HL and LL (table 5).
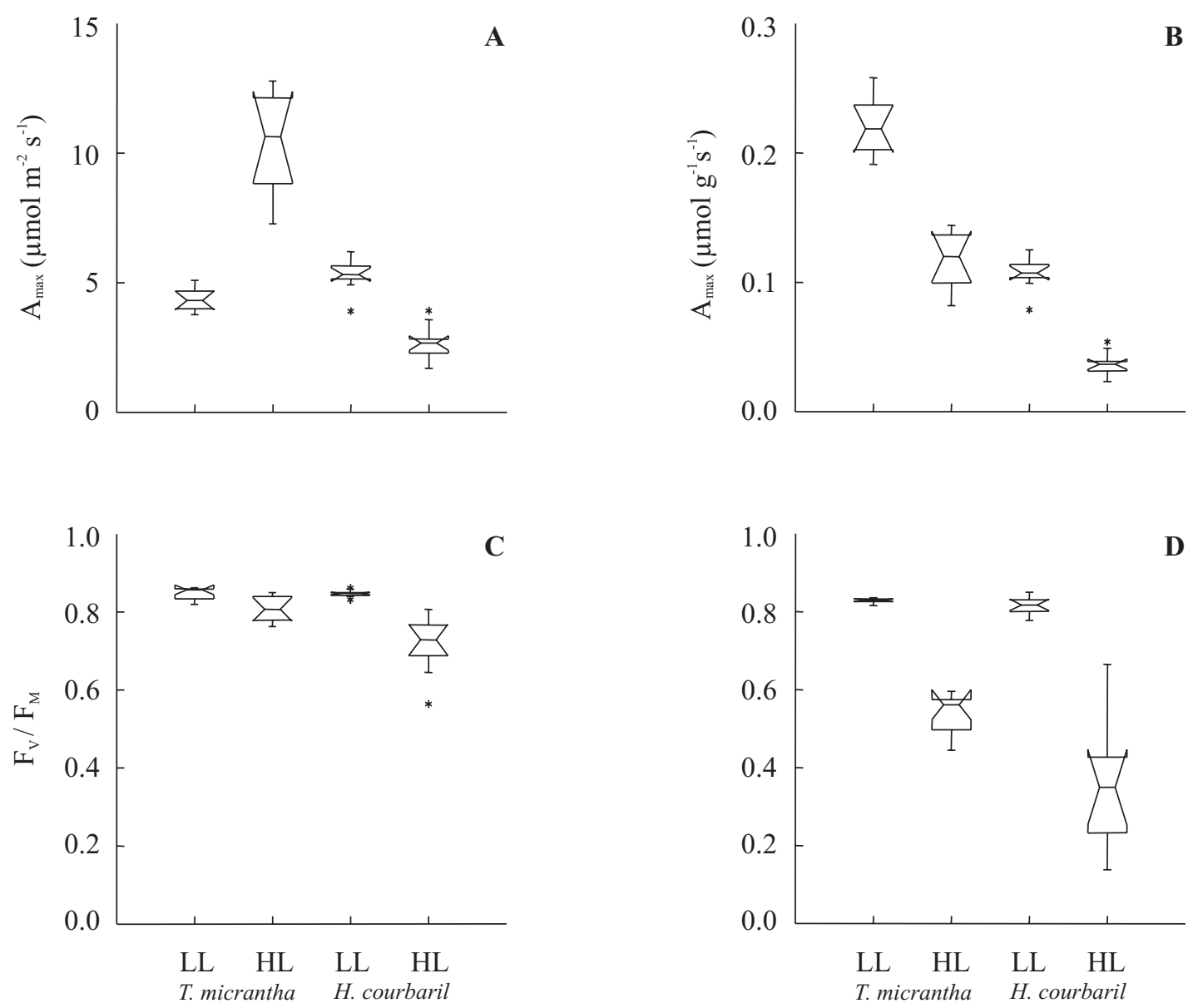

Figure 2. Notched box plots of maximum values of the $\mathrm{CO}_{2}$ net assimilation rate $\left(\mathrm{A}_{\max }\right)$ in $\mu \mathrm{mol} \mathrm{m} \mathrm{m}^{-2} \mathrm{~s}^{-1}(\mathrm{~A})$ and in $\mu \mathrm{mol} \mathrm{g} \mathrm{g}^{-1} \mathrm{~s}^{-1}(\mathrm{~B})$ $(n=09)$ and of fluorescence parameter $\mathrm{F}_{\mathrm{v}} / \mathrm{F}_{\mathrm{m}}$ ratio pre-dawn $(\mathrm{C})$ and at midday $(\mathrm{D})(n=10)$ for seedlings of Trema micrantha (pioneer) and Hymenaea courbaril var. stilbocarpa (climax) under low light (LL) and high light (HL). Central horizontal bars represent median values. Upper and lower values vertical bars represent $4^{\text {th }}$ and $1^{\text {st }}$ percentiles, respectively. Notches surrounding the median represent median $95 \%$ confidence intervals. Overlapping of median confidence intervals indicate similarity of groups with $95 \%$ confidence level (* = outliers). 
Table 2. Means $\pm s_{\bar{x}}$ of transpiration rate (E) and stomatal conductance $\left(g_{\mathrm{s}}\right)$ in $\mathrm{mol} \mathrm{m}^{-2} \mathrm{~s}^{-1}$ for seedlings of Trema micrantha (pioneer) and Hymenaea courbaril var. stilbocarpa (climax) under low light (LL) and high light (HL) treatments $(n=10)$. Uppercase letters indicate comparisons between means within rows (light treatment) and lowercase letters indicate comparisons between means within columns (species). Means followed for the same letter are statistically the same by Tukey test with 5\% of significance.

\begin{tabular}{|c|c|c|c|c|}
\hline \multirow{2}{*}{ Species } & \multicolumn{2}{|c|}{$\mathrm{E}$} & \multicolumn{2}{|c|}{$g_{\mathrm{s}}$} \\
\hline & LL & HL & LL & $\mathrm{HL}$ \\
\hline Trema micrantha & $1.30 \pm 0.09 \mathrm{aB}$ & $2.9 \pm 0.2 \mathrm{aA}$ & $0.14 \pm 0.01 \mathrm{aA}$ & $0.15 \pm 0.01 \mathrm{aA}$ \\
\hline Hymenaea courbaril & $1.2 \pm 0.1 \mathrm{aA}$ & $1.14 \pm 0.09 \mathrm{bA}$ & $0.13 \pm 0.01 \mathrm{aA}$ & $0.030 \pm 0.003 \mathrm{bA}$ \\
\hline
\end{tabular}
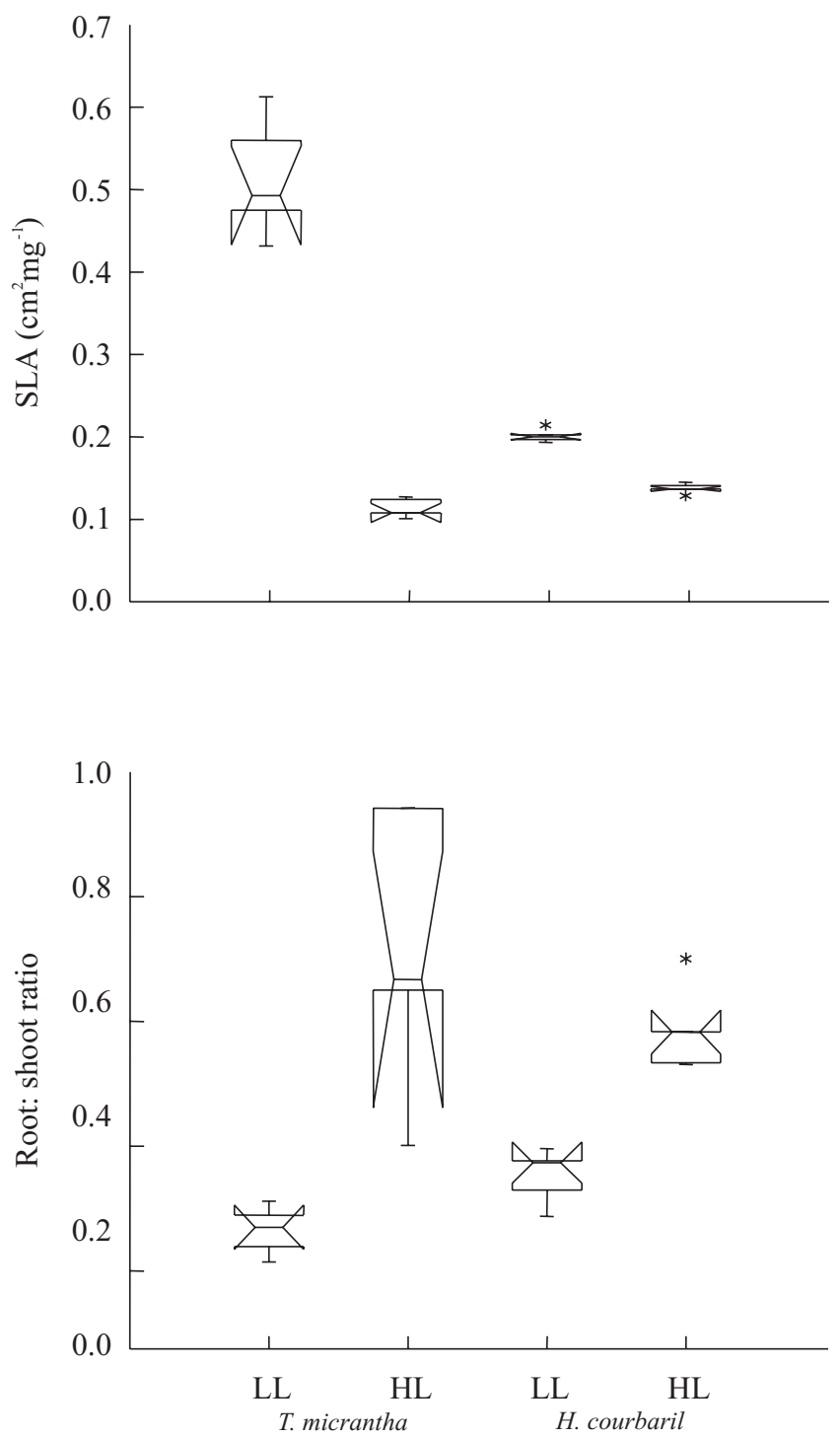

Figure 3. Notched box plots of specific leaf area in $\mathrm{cm}^{2} \mathrm{mg}^{-1}$ (SLA) and root: shoot ratio for seedlings of Trema micrantha (pioneer) and Hymenaea courbaril var. stilbocarpa (climax) under low light (LL) and high light (HL) $(n=5)$. See details about notched box plots in figure $2(*=$ outliers).
Both species grown under HL showed higher root:shoot ratio than in LL (figure 3). Under LL, H. courbaril presented higher root:shoot ratio than T. micrantha.

\section{Discussion}

The general trend of pioneer species presenting higher photosynthetic capacity and saturation light points than climax species was also true for the two semideciduous species studied. Moreover, photosynthetic rates around $10 \mu \mathrm{mol} \mathrm{m} \mathrm{m}^{-2} \mathrm{~s}^{-1}$ observed in Trema micrantha under HL could be considered similar to shade intolerant and pioneer semideciduous species studied by Kitajima (1994) and several pioneer rainforests species (Ramos \& Grace 1990, Strauss-Debenedetti \& Bazzaz 1991, Tinoco-Ojanguren \& Pearcy 1995, Zipperlen \& Press 1996, Barker et al. 1997, Scholes et al. 1997). Cecropia obtusifolia Bertol. is an exception to this since it shows much higher values (22.4 $\left.\mu \mathrm{mol} \mathrm{m}^{-2} \mathrm{~s}^{-1}\right)$ (Tinoco-Ojanguren \& Pearcy 1995), as also some species of the genus Shorea that shows lower photosynthetic capacity values (between 4-6 $\mu \mathrm{mol}$ $\mathrm{m}^{-2} \mathrm{~s}^{-1}$ ) (Barker et al. 1997, Scholes et al. 1997).

On the other hand, the photosynthetic capacity recorded for Hymenaea courbaril (L.) var. stilbocarpa under LL was very high when compared with other semideciduous (Kitajima 1994) and rainforest climax species grown under both high and low light levels (Langenheim et al. 1984; Ramos \& Grace 1990, StraussDebenedetti \& Bazzaz 1991, Turnbull 1991, Thompson et al. 1992, Tinoco-Ojanguren \& Pearcy 1995, Zipperlen \& Press 1996, Barker et al. 1997, Sholes et al. 1997). It is also interesting to compare the results of $H$. courbaril var. stilbocarpa, an endemic semideciduous variety, with the same species from Amazonian rainforest (Langenheim et al. 1984). According to Langenheim et al. (1984), $H$. courbaril from Amazonia showed photosynthetic capacity around 5.0 and 3.5 when growing, respectively, 


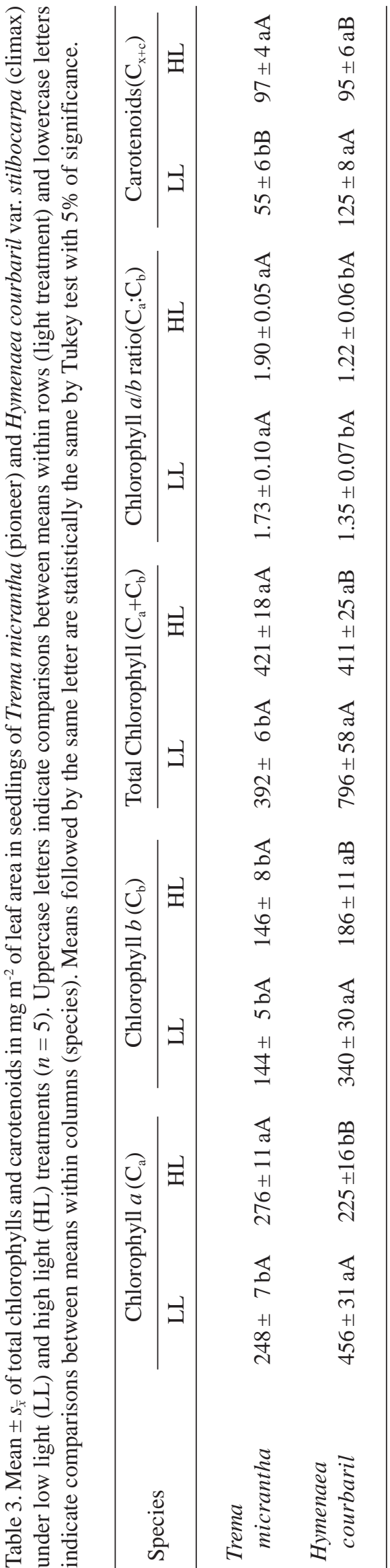

under $100 \%$ and $6 \%$ of sunlight. These treatments were similar to our HL and LL conditions. Thus, individuals from the semideciduous forest exhibited higher photosynthetic capacity than individuals from the rainforest under low irradiance.

Climax species often have larger chlorophyll and carotenoid pools and a lower chlorophyll $\mathrm{a} / \mathrm{b}$ ratio than pioneer species. This is probably due to the necessity of an increase in the capacity of light capture in places where it is less available (Henry \& Aarssen 1997). $H$. courbaril is not an exception to this. In contrast, $T$. micrantha presented a higher amount of total carotenoids under HL than under LL, which may indicate that the carotenoid pool is playing a different role in both species at contrasting light regimes. Even though we have only measured the total carotenoid pool, which is not necessarily directly related to a high dynamics of the xanthophyll cycle (Demmig-Adams \& Adams 1992), the pattern observed may be used as an indirect evidence of the engagement of a higher carotenoid pool in photoprotection in leaves of T. micrantha exposed to HL.

$H$. courbaril showed very low values of stomatal conductance when exposed to the high irradiance and temperatures of a cloudless day under HL. This could explain in part the low $\mathrm{CO}_{2}$ assimilation rates observed for this species under HL. Moreover, $H$. courbaril may have an inability to increase water transport under the high transpiration demand.

Apparent quantum yield and $\mathrm{F}_{\mathrm{v}} / \mathrm{F}_{\mathrm{m}}$ ratio at midday of both plants studied were very low when compared to rainforest climax species and did not show a complete recover at pre-dawn (Thompson et al. 1992, Langenheim et al. 1984, Lovelock et al. 1994, Zipperlen \& Press 1996, Barker et al. 1997, Scholes et al. 1997). However, with the exception of similar light levels in the studies of Langenheim et al. (1984) and Ishida et al. (1999), daily and maximum PFD under HL in our experiment were much higher than the high light treatments of those studies. In addition, considering the low values of $\mathrm{A}_{\max }, \mathrm{A}_{\text {sat }}$ and chlorophyll $a$ content we have evidence to suggest the occurrence of chronic photoinhibition (Osmond 1994) in H. courbaril under HL and a higher susceptibility of $H$. courbaril than T. micrantha to this process. We have some evidence, however, that the intensity of photoinhibition in $H$. courbaril increased over the course of the experiment (results from pilot light response curves carried out during the first month of experiment; data not shown). Thus, we speculate that prolonged exposition to high light levels might have led to a shift from dynamic to chronic photoinhibition in this species. At the moment it is unclear which processes were involved. Hence, the expressive accumulation of 
Table 4. Means $\pm s_{\bar{x}}$ of height $(\mathrm{cm})$ and leaf area $\left(\mathrm{cm}^{2}\right)$ for seedlings of Trema micrantha (pioneer) and Hymenaea courbaril var. stilbocarpa (climax) grown for 130 days under low light (LL) and high light (HL) treatments (HL) $(n=05)$. Uppercase letters indicate comparisons between means within rows (light treatment) and lowercase letters indicate comparisons between means within columns (species). Means followed for the same letter are statistically the same by Tukey test with 5\% of significance.

\begin{tabular}{lcrlrr}
\hline \multirow{2}{*}{ Species } & \multicolumn{2}{c}{ Height $(\mathrm{cm})$} & & \multicolumn{2}{c}{ Leaf area $\left(\mathrm{cm}^{2}\right)$} \\
\cline { 2 - 3 } \cline { 5 - 6 } & LL & HL & & LL & HL \\
\hline \multirow{2}{*}{ Trema micrantha } & $46 \pm 4 \mathrm{bA}$ & $27 \pm 1 \mathrm{bB}$ & & $1183 \pm 44 \mathrm{aA}$ & $381 \pm 16 \mathrm{bB}$ \\
Hymenaea courbaril & $60 \pm 2 \mathrm{aA}$ & $43 \pm 2 \mathrm{aB}$ & & $938 \pm 67 \mathrm{bA}$ & $618 \pm 46 \mathrm{aB}$ \\
\hline
\end{tabular}

biomass in $H$. courbaril under HL could be justified by the occurrence of a delayed chronic photoinhibition.

As observed by Kitajima (1994) and Lee et al. (1997), biomass accumulation responses across species and treatments were not proportional to $\mathrm{CO}_{2}$ assimilation rates. Diurnal net $\mathrm{CO}_{2}$ assimilation in clear days was much higher in $T$. micrantha than $H$. courbaril under HL as well as maximum assimilation rates, mainly on an area basis $\left(\mathrm{A}_{\max }\right)$. However, total dry mass was significantly higher in $H$. courbaril. This discrepancy between carbon gain and $\mathrm{CO}_{2}$ assimilation rates between species under HL could be explained in part by increased susceptibility of photoinhibition in $H$. courbaril. As seen before, photosynthetic rates of $H$. courbaril under HL were higher in the beginning of the experiment when photoinhibition was probably not yet chronic.

Differences in investment on leaves and roots might also explain the observed pattern of biomass accumulation. Leaf area of $H$. courbaril under HL was 1.6-fold higher than T. micrantha. The higher amount of leaf available for carbon assimilation of the whole plant, may in part explain the 1.8-fold higher biomass accumulation in $H$. courbaril. The high respiration of $T$. micrantha under HL, particularly from leaves and roots, can also help to explain the lower increment in biomass in this species than in $H$. courbaril. Total plant mass increased from LL to HL by $77 \%$ in T. micrantha and $45 \%$ in $H$. courbaril, but root mass increased much more than total mass $(248 \%$ and $104 \%$, respectively, for T. micrantha and $H$. courbaril). T. micrantha also exhibited a greater increase in root: shoot ratio from LL to HL. These, in conjunction with the higher temperatures in HL, could have significantly increased leaf and root respiration under HL, resulting in a lower accumulation of biomass in T. micrantha.

Also, the higher biomass accumulation of $H$. courbaril could be related to its greater seed size. The large seed reserves could provide an ample reserve of nutrients during the period immediately after germination allowing a higher accumulation of biomass by seedlings in the period studied. In later developmental stages, however, it is possible to observe changes in growth responses, such as Rodrigues (1999) found that T. micrantha shows higher and faster growth than $H$. courbaril after four years growing in a disturbed fragment forest. In contrast, the efficiency of $H$. courbaril in the maintenance of a positive carbon balance and biomass increase in HL as well as in LL could be an indicative of the capacity of this species to occupy different light environments in the semideciduous forests. These corroborate the results of Mazzei et al. (1999) where saplings of $H$. courbaril grown under $100 \%$ and $50 \%$ of sunlight exhibited higher total biomass than under $30 \%$ and $10 \%$ of sunlight.

Under LL, both species presented higher SLA and shoot/root ratios. These characteristics seem to bring benefits by increasing light capture and, consequently, increasing the ratio between photosynthesis and respiration of the whole plant. This may contribute to the maintenance of a positive carbon balance and survival by optimizing growth under these conditions (Givnish 1988, Kitajima 1994, Lee et al. 1997). It is interesting to note, however, that $T$. micrantha presented higher SLA, LA and lower root:shoot ratio than $H$. courbaril under low light. This could indicate an unusual adjustment to shade conditions in the pioneer species, which was also evidenced by high $\mathrm{A}_{\max }$ in a mass basis. However, leaves of T. micrantha showed a lower daily-integrated carbon assimilation ( $\mathrm{A}_{\text {int }}$, figure 1), a lower biomass accumulation (table 5) and were very susceptible to pathogens and herbivores, dying as soon as the experiment finished. In the case of climax species, lower values of SLA than in pioneer species have been correlated to the presence of chemical and structural defenses (Kitajima 1994, Huante \& Rincón 1998). This is an important characteristic because, as pointed out by Bazzaz (1984) the attack of herbivores and pathogens in the understory is probably more intensive than in gaps. $H$. courbaril and other climax species 


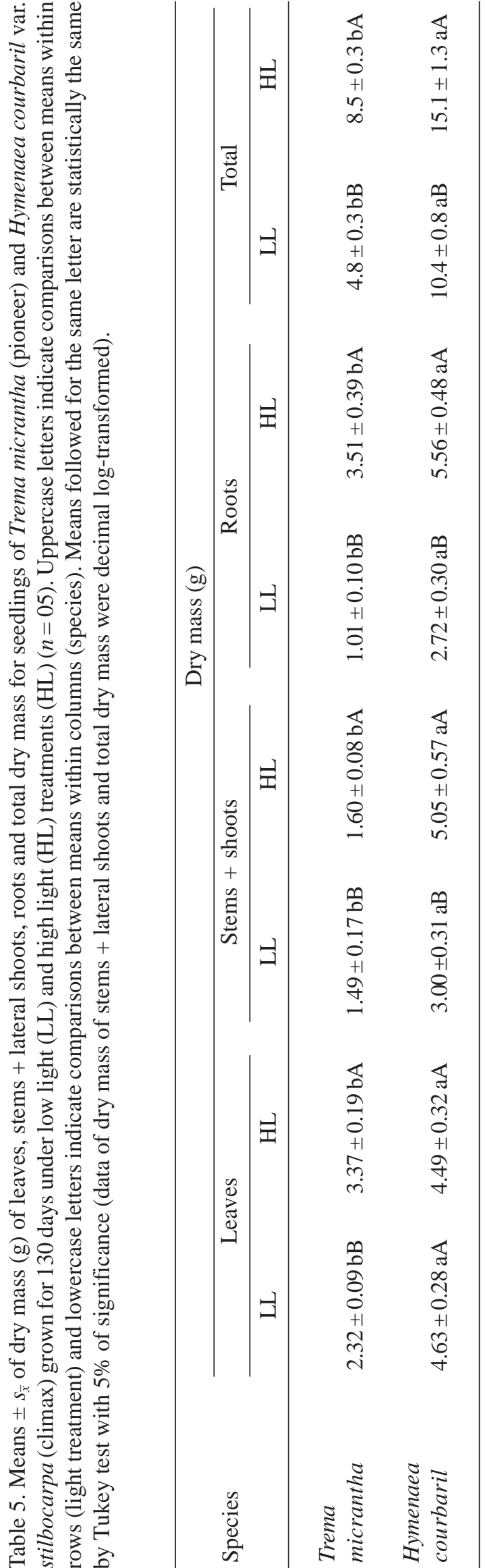

from semideciduous (Kitajima 1994) and rainforests (Tinoco-Ojanguren \& Pearcy 1995, Huante \& Rincón 1998) showed higher root:shoot ratio than pioneers when grown under low irradiance. According to Kitajima (1994), a well-established root system can enhance survivorship in the shade. On the other hand, this characteristic seems also to be advantageous to plants subjected to seasonal changes of light, temperature and water availability of semideciduous understory as well as to sharp changes of light and temperatures in gaps where there is a high water and nutrients demand (Naidu \& DeLucia 1997).

Overall, both species studied presented photosynthetic and morphological characteristics correlated to the microhabitat where the species are commonly found or to the ecological group to which they belong. Even though considering the difficulties to compare species responses across different ages, light regimes and growth conditions, we can point out that $H$. courbaril exhibited a greater ecophysiological range of responses to contrasting light levels than generally observed for rainforests climax species. Accepting that the studied species belong to extreme groups in the response continuous of tree species of semideciduous forests, the responses of $H$. courbaril indicated that in this type of forest, characteristics of climax species or late succession species could be less extreme in terms of specialization on deeply shaded environments than species of the same group from other tropical forests.

Acknowledgments - This work was supported by Fundação de Amparo à Pesquisa do Estado de São Paulo (FAPESP) and Conselho Nacional de Desenvolvimento Científico e Tecnológico (CNPq). We thank C.A. Joly (UNICAMP) for lending us LCA-4 and P.L. da C. Alves (UNESP) for PEA, S. Gandolfi for providing light data of Santa Genebra Reserve and F.R. Scarano and two anonymous referees for critical comments on the manuscript.

\section{References}

BARKER, M.G., PRESS, M.C., \& BROWN, N.D. 1997. Photosynthetic characteristics of dipterocarp seedlings in three tropical rain forest light environments: a basis for niche partitioning? Oecologia 112:453-463.

BAZZAZ, F.A. 1979. The physiological ecology of plant succession. Annual Review of Ecology and Systematics 10:351-371.

BAZZAZ, F.A. 1984. Dynamics of wet tropical forests and their species strategies. In Physiological ecology of plants of the wet tropics (E. Medina, M.A. Mooney \& C. Vázquez-Yanes, eds.). Dr. Junk Publishers, p.233-243.

CHAZDON, R.L. 1986. Light variation and carbon gain in rain forest understorey palms. Journal of Ecology 74:995-1012. 
CHAZDON, R.L. \& FETCHER, N. 1984. Light environments of tropical forests. In Physiological ecology of plants of the wet tropics (E. Medina, H.A. Mooney \& C. VázquezYanes, eds.). Dr. W. Junk Publishers, p.27-36.

DEMMIG-ADAMS, B. \& ADAMS, W.W. 1992. Carotenoid composition in sun and shade leaves of plants with different life forms. Plant, Cell and Environmental 15:411-419.

FERRETI, A.R., KAGEYAMA, P.Y., ÁRBOCZ, G.F., SANTOS, J.D., BARROS, M.I., LORZA, R.F. \& OLIVEIRA, C. 1995. Classificação das espécies arbóreas em grupos ecológicos para a revegetação com nativas no Estado de São Paulo. Florestar estatístico 3. São Paulo: Fundação Florestal, Fundo Florestal.

GANDOLFI, S. 2000. História natural de uma floresta estacional semidecidual no Município de Campinas (São Paulo, Brasil). Tese de Doutorado, Universidade Estadual de Campinas, Campinas.

GANDOLFI, S., LEITÃO-FILHO, H.F. \& BEZERRA, C.L.F. 1995. Levantamento florístico e caráter sucessional das espécies arbustivo-arbóreas de uma Floresta Mesófila Semidecídua no município de Guarulhos, SP. Revista Brasileira de Biologia 55:753-767.

GIVNISH, T.J. 1988. Adaptation to sun and shade: A whole plant perspective. Australian Journal of Plant Physiology 15:63-92.

GOMEZ, K.A. \& GOMEZ, A.A. 1984. Statistical procedures for agricultural research. Wiley, New York.

HENRY, H.A.L. \& AARSSEN, L.W. 1997. On the relationship between shade tolerance and shade avoidance strategies in woodland plants. Oikos 80:575-582.

HOAGLAND, D.R. \& ARNON, D.I. 1938. The water-culture method for growing plants without soil. Agricultural Experiment Station Circular. University of California, Berkeley, 39 p. (Circular 347).

HOGAN, K.P., SMITH,A.P.\&SAMANIEGO,M. 1995. Gasexchange in six tropical semi-deciduous forest canopy tree species during the wet and dry seasons. Biotropica 27:324-333.

HOLDRIDGE, L.R. 1967. Life Zone Ecology. Tropical Scientific Center, San Jose, Costa Rica.

HUANTE, P. \& RINCÓN, E. 1998. Responses to light changes in tropical deciduous woody seedlings with contrasting growth rates. Oecologia 113:53-66.

IBGE 1992. Manual técnico da vegetação brasileira. Manuais Técnicos de Geociências n⿳o 01. Fundação Instituto Brasileiro de Geografia e Estatística, Rio de Janeiro.

ISHIDA, A., NAKANO, T., MATSUMOTO, Y., SAKODA, M. \& ANG, L.H. 1999. Diurnal changes in leaf gas exchange and chlorophyll fluorescence in tropical tree species with contrasting light requirements. Ecology Research 14:77-88.

KITAJIMA, K. 1994. Relative importance of photosynthetic traits and allocation patterns as correlates of seedling shade tolerance of 13 tropical trees. Oecologia 98:419-428.

LANGENHEIM, C.B., OSMOND, C.B.,BROOKS, A.\& FERRAR, P.J. 1984. Photosynthetic responses to light in seedlings of selected Amazonian and Australian rainforest tree species. Oecologia 63:215-224.
LEE, D.W., OBERBAUER, S.F., KRISHNAPILAY, B., MANSOR, M., MOHAMAD, H. \& YAP, S.K. 1997. Effects of irradiance and spectral quality on seedling development of two southeast asian Hopea species. Oecologia 110:1-9.

LICHTENTHALER, H.K. 1987. Chlorophylls and carotenoids: pigments of photosynthetic biomembranes. In Methods in Enzymology (L. Packer \& R. Douce, eds.). Academic Press, San Diego, v.148. p.350-382.

LOVELOCK, C.E., JEBB, M. \& OSMOND, C.B. 1994. Photoinhibition and recovery in a plant species: response to disturbance. Oecologia 97:297-307.

LORENZI, H. 1992. Árvores Brasileiras: Manual de identificação e cultivo de plantas arbóreas nativas do Brasil. Editora Plantarum, São Paulo, Brasil.

MARTÍNEZ-RAMOS, M. 1985. Claros, ciclos vitales de los arboles tropicales y regeneración natural de las selvas altas perennifolias. In Investigaciones sobre la regeneración de selvas altas en Veracruz, México (A. Gomez-Pompa \& S.R. Del Amo, eds.). Alhambra Mexicana S.A., Xalapa, v.II, p.191-239.

MATTHES, L.A.F. 1992. Dinâmica da sucessão secundária em mata após a ocorrência de fogo - Santa Genebra Campinas, São Paulo. Tese de doutorado, Universidade Estadual de Campinas, Campinas.

MAZZEI, L.J., SOUSA-SILVA, J.C., FELFILI, J.M., REZENDE, A.V. \& FRANCO, A.C. 1999. Crescimento de plântulas de Hymenaea courbaril L. var. stilbocarpa (Hayne) Lee \& Lang. em viveiro. Boletim do Herbário Ezechias Paulo Heringer 4:21-29.

MCGILL, R., TUKEY, J.W. \& LARSEN, W.A. 1978. Variations of box plots. The American Statistician 32:12-16.

MORELLATO, L.P.C. \& LEITÃO FILHO, H.F. 1995. Introdução. In Ecologia e preservação de uma floresta tropical urbana: Reserva de Santa Genebra (L.P.C. Morellato \& H.F. LeitãoFilho, eds.). Editora da UNICAMP, Campinas, p.15-18.

NAIDU, S.L. \& DELUCIA, E.H. 1997. Growth, allocation and water relations of shade-grown Quercus rubra L. saplings exposed to a late-season canopy gap. Annals of Botany 80:335-344.

OLIVEIRA-FILHO, A.T. \& FONTES, M.A. 2000. Patterns of floristic differentiation among Atlantic Forests in Southestern Brazil and the influence of climate. Biotropica 32:793-810.

OSMOND, C.B. 1994. What is photoinhibition? Some insights from comparison of shade and sun plants. In Photoinhibition of photosynthesis_from molecular mechanisms to the field (N.R. Baker \& J.R. Bowyer, eds.). Bios Scientific Publishers, Oxford, p. 1-24.

PICKETT, S.T.A. 1983. Differential adaptation of tropical tree species to canopy gaps and its role in community dynamics. Tropical Ecology 24:68-84.

PHILLIPS O.L., HALL, P., GENTRY, A.H., SAWYER, S.A. \& VASQUEZ, R. 1994. Dynamics and species richness of tropical rain forests. Proceedings of the National Academy of Science 91:2805-2809. 
PRIOUL, J.L. \& CHARTIER, P. 1977. Partitioning of transfer and carboxylation components of intracellular resistance to photosynthetic $\mathrm{CO}_{2}$ fixation: A critical analysis of the methods used. Annals of Botany 41:789-800.

RAMOS, J. \& GRACE, J. 1990. The effects of shade on the gas exchange of seedlings of four tropical trees from Mexico. Functional Ecology 4:667-677.

RODRIGUES, R.R. 1995. A sucessão florestal. In Ecologia e preservação de uma floresta tropical urbana: Reserva de Santa Genebra (L.P.C. Morellato \& H.F. Leitão-Filho, eds.). Editora da UNICAMP, Campinas, p. 30-35.

RODRIGUES, R.R. 1999. Colonização e enriquecimento de um fragmento florestal urbano após a ocorrência de fogo, Fazenda Santa Eliza, Campinas, SP: Avaliação temporal da regeneração natural (66 meses) e do crescimento (51 meses) de 30 espécies florestais plantadas em consórcios sucessionais. Tese de livre docência, Universidade de São Paulo, Piracicaba.

SCHOLES, J.D., PRESS, M.C. \& ZIPPERLEN, S.W. 1997. Differences in light energy utilization and dissipation between dipterocarp rain forest tree seedlings. Oecologia 109:41-48.

SOKAL, R.R. \& ROHLF, F.J. 1995. Biometry (The principles and practice of statistics in biological research). Freeman, New York.

SOUZA, R.P. 1996. Germinação, crescimento, atividade fotossintética e translocação de compostos de carbono em espécies arbóreas tropicais: Estudo comparativo e influência de sombreamento natural. Tese de doutorado, Universidade Estadual de Campinas, Campinas.
SOUZA, R.P. \& VÁLIO, I.F.M. 2001. Seed size, seed germination and seedling survival of Brazilian tropical tree species differing in succesional status. Biotropica 33:447-457.

STRAUSS-DEBENEDETTI, S. \& BAZZAZ, F.A. 1991. Plasticity and acclimation to light in tropical Moraceae of different successional position. Oecologia 87:377-387.

SYSTAT 1992. SYSTAT for Windows: Graphics, Version 5, Evanston.

SWAINE, M.D. \& WHITMORE, T.C. 1988. On the definition of ecological species groups in tropical rain forests. Vegetatio 75:81-86.

THOMPSON, W.A., HUANG, L.K. \& KRIEDEMANN, P.E. 1992. Photosynthetic response to light and nutrients in sun-tolerant and shade-tolerant rainforest trees. II. Leaf gas exchange and component processes of photosynthesis. Australian Journal of Plant Physiology 19:19-42.

TINOCO-OJANGUREN, C. \& PEARCY, R.W. 1995. A comparison of light quality and quantity effects on the growth and steady-state and dynamic photosynthetic characteristics of three tropical tree species. Functional Ecology 9:222-230.

TURNBULL, M.H. 1991. The effect of light quantity and quality during development on the photosynthetic characteristics of six Australian rainforest tree species. Oecologia, 87: 110-117.

ZAR, J.H. 1996. Biostatistical analysis. Prentice-Hall, New Jersey.

ZIPPERLEN, S.W. \& PRESS, M.C. 1996. Photosynthesis in relation to growth and seedling ecology of two dipterocarp rainforest tree species. Journal of Ecology 84:863-876. 